\title{
PENERAPAN MODEL PEMBELAJARAN RCCDE UNTUK MENINGKATKAN AKTIVITAS BELAJAR SISWA di MA MA'ARIF AMBULU
}

\author{
1Faiqotul Himmah, 2 Siti Roudlotul Hikamah, ${ }^{3}$ Umi Nurjanah \\ ${ }_{123}$ Pendidikan Biologi, Universitas Islam Jember \\ 1Ilmifahim1@gmail.com, 2sitihikamah@yahoo.com, ${ }^{3}$ kholidumi@yahoo.com
}

\begin{abstract}
ABSTRAK
Keberhasilan pembelajaran abad 21 dapat diukur dengan meningkatnya dan antusiasnya siswa dalam mengikuti kegiatan pembelajaran. Peneliti melakukan wawancara terhadap guru mata pelajaran IPA di kelas XI IPA 2 MA Ma'arif Ambulu, dan diperoleh data bahwa keaktifan siswa dalam mengikuti pembelajaran mencapai 30\% dimana data tersebut berarti bahwa siswa siswi- masih kurang aktif. Penelitian ini bertujuan untuk mengetahui peningkatan aktivitas hasil belajar siswa dalam mempelajari sistem ekskresi dengan menggunakan model pembelajaran RCCDE. Jenis penelitian yang digunakan adalah PTK. Prosedur yang digunakan adalah model siklus. Berdasarkan penelitian presentase aktivitas belajar siswa pada siklus I sebesar 52,71\% dengan kualifikasi cukup aktif dan siklus II dengan presentase 70,00\% dengan kualifikasi aktif. Hal tersebut membuktikan bahwa aktivitas belajar siswa meningkat dengan diterapkannya model pembelajaran RCCDE.
\end{abstract}

Kata kunci : Model Pembelajaran RCCDE, Aktivitas belajar siswa

\section{PENDAHULUAN}

\section{Latar Belakang}

Menurut UU RI No. 20 tahun 2003 tentang Sistem Pendidikan Nasional bab II Pasal 3 sebagai berikut: "Pendidikan bertujuan untuk mengembangkan potensi siswa agar menjadi manusia yang beriman dan bertaqwa kepada Tuhan Yang Maha Esa, berakhlak mulia, sehat, berilmu, cakap, kreatif, mandiri, dan menjadi warga negara yang demokratis serta bertanggung jawab". Keberhasilan pendidikan abad 21 dapat diukur dengan meningkatnya dan antusiasnya siswa dalam mengikuti kegiatan pembelajaran. Salah satu faktor yang mempengaruhi adalah kegiatan pembelajaran di kelas, pembelajaran di kelas sangat berpengaruh dalam tercapainya prestasi belajar yang baik pula (Sunarto, 2013). Untuk mencapai prestasi maka siswa juga harus aktif dalam mengikuti pembelajaran di kelas. Dari hasil wawancara dengan guru pengampu mata pelajaran di kelas XI IPA 2 MA Ma'arif
Ambulu, di dapatkan bahwa persentase keaktifan belajar siswa hanya mencapai $30 \%$ saja dengan kualifikasi kurang aktif. Hal ini didasari karna model pembelajaran yang digunakan oleh guru dalam mengajar masih menggunakan model pembelajaran konvensional, yakni ceramah dan diskusi saja. Untuk itu peneliti memberikan inovasi model pembelajaran baru untuk meningkatkan aktifitas belajar siswa, yakni metode RCCDE. Metode ini bertujuan untuk menyampaikan informasi pembelajaran dengan cara mengajak siswa untuk berdiskusi

\section{Rumusan Masalah}

1. Adakah peningkatan hasil belajar siswa kelas XI IPA 2 melalui penerapan model Pembelajaran RCCDE di MA Ma'arif Ambulu?

2. Adakah peningkatan aktivitas siswa kelas XI IPA 2 melalui penerapan model pembelajaran RCCDE di MA Ma'arif Ambulu? 


\section{Tujuan Penelitian}

1. Untuk mengetahui penerapan model pembelajaran RCCDE terhadap hasil belajar siswa kelas XI IPA 2 MA Ma'arif Ambulu pada materi sistem ekskresi.

2. Untuk mengetahui penerapan model pembelajaran RCCDE terhadap aktivitas siswa kelas XI IPA 2 MA Ma'arif Ambulu pada materi sistem ekskresi.

\section{KAJIAN PUSTAKA}

\section{a. Pendidikan}

Pendidikan merupakan suatu sarana yang digunakan untuk meningkatkan kualitas sumber daya manusia yang dimiliki. Pendidikan pada hakikatnya adalah sebuah usaha dimana siswa diharapkan agar dapat memecahkan persoalan - persoalan yang terjadi dalam kehidupannya (Suarjo, 2016). Upaya peningkatan kualitas pendidikan yang sesuai dengan perkembangan jaman dan teknologi dapat meningkatkan pengetahuan siswa.

Dengan adanya proses pembelajaran yang sesuai dengan tujuan utama dari pembelajaran maka akan menghasilkan pula output siswa yang memiliki hasil belajar yang baik dan aktif. Untuk itu proses yang baik dalam pendidikan sangat dibutuhkan dan sangat penting bagi setiap lembaga pendidikan.

\section{b. Hasil Belajar}

Menurut (Slameto, 2013) belajar adalah suatu tindakan yang dilakukan untuk mencapai perubahan sebagai hasil pengalaman dan interaksi dengan lingkungan sekitarnya. Seseorang yang telah mengikuti suatu pembelajaran maka akan mengalami perubahan baik dari segi pengetahuan, kreatifitas ataupun sikap pada diri seseorang ke arah yang lebih baik lagi.

Maka dapat disimpulkan bahwa hasil belajar merupakan serangkaian kemampuan yang dimiliki oleh siswa setelah menerima pengalaman belajarnya. Hal ini ditandai dengan meningkatnya kemampuan berpikir dan pengetahuan siswa itu sendiri. Untuk mencapai hasil belajar yang baik dan maksimal maka ada beberapa faktor yang harus diperhatikan. Dari sekian banyak faktor yang mempengaruhi hasil belajar dapat digolongkan menjadi 3 macam yaitu: Faktor Stimulus Belajar, Fantor Metode dan Model Belajar selanjutnya faktor Individual.

\section{c. Aktivitas Belajar}

Aktivitas belajar siswa merupakan suatu modal utama untuk mencapai suatu keberhasilan dalam proses pembelajaran. Pembalajaran dikatakan berhasil dan berkualitas apabila seluruh atau sebagian siswa terlibat secara aktif, baik fisik, mental maupun sosial dalam kegiatan pembelajaran yang diikuti (Wibowo, 2016).

Berdasarkan uraian tersebut aktivitas siwa dapat dilihat dari beberapa hal seperti memperhatikan (Visual Activities), mendengarkan, berdiskusi, kesiapan siswa, bertanya, mendengarkan dan memecahkan soal (Mental Activities). Keaktifan siswa dalam mengikuti pembelajaran sangat berpengaruh terhadap hasil belajar dan pengetahuan siswa.

\section{d. Model Pembelajaran}

Pembelajaran perlu direncanakan, dilaksanakan, dinilai dan diawasi dengan sebaik-baiknya agar proses pembelajaran sesuai dengan tujuan yang diinginkan. Model pembelajaran adalah suatu perencanaan atau pola yang digunakan sebagai pedoman dalam merencanakan pembelajaran di kelas atau pembelajaran tutorial (Afandi, 2013). Model pembelajaran mengacu pada pendekatan yang akan digunakan, termasuk didalamnya tujuan pengajaran, tahapan dalam kegiatan pembelajaran, lingkungan pembelajaran, dan pengelolaan kelas. Pemilihan model 
pembelajaran yang tepat akan sangat berpengaruh terhadap hasil belajar siswa.

\section{e. Model pembelajaran RCCDE (Reading, Concept map, Conection, Discussion, Evaluation)}

Sintak dari model pembelajaran RCCDE adalah sebagai berikut: Reading, Cancept Map, Connection, Discussion, Evaluation.

\section{1). Reading}

Menurut (Soleha, 2019) membaca dapat diartikan sebagai kemampuan berbahasa tulis yang bersifat represif, karna dengan membaca seseorang akan memperoleh informasi baru, pengalaman baru ataupun pengetahuan baru dari hasil membaca. Proses membaca di dalam suatu pembelajaran sangatlah penting, karena dengan membaca siswa akan memahami, mengerti dan mendapatkan pengetahuan baru dari suatu buku yang telah mereka baca.

\section{2). Cancept Map}

Concept Map atau peta konsep adalah suatu alat yang digunakan untuk mempermudah dan menyederhanakan suatu pengetahuan dengan cakupan yang luas menjadi suatu bentuk yang lebih sederhana dengan tetap menjelaskan informasi pokok yang terkandung (Khikmayanti et al, 2012). Dalam Pembuatan peta konsep otak kanan dan otak kiri saling terlibat, sehingga akan mempermudah siswa untuk mengahafal dan mengingat hasil yang dibuat dalam peta konsep tersebut. Pencarian ide pokok dalam suatu paragaf akan mempermudah siswa dalam menghafal dan memahami konsep materi yang akan mereka pelajari.

\section{3). Connection}

Menurut (Soleha et al., 2019) Connection atau penghubung adalah salah satu teknik yang digunakan untuk mencari hubungan antara sumber yang di baca dengan kejadian nyata. Ada banyak macam media yang dapat digunakan untuk membantu siswa dalam mengingat dan menghafal suatu mata pelajaran. Media dapat digunakan guru sebagai penghubung atau stimulus kepada siswa, sehingga dapat menghasilkan hasil yang baik.

\section{4). Discussion}

Diskusi merupakan metode mengajar dengan memecahkan masalah yang dihadapi, dimana setiap peserta diskusi mengajukan argumentasinya untuk memperkuat pendapatnya (Prianto, 2017). Teknik diskusi merupakan teknik belajar mengajar yang dilakukan oleh seorang guru di sekolah dengan siswa. Di dalam diskusi terjadi proses interaksi antara dua orang atau lebih individu yang saling tukar menukar pengalaman, informasi dan dapat memecahkan masalah. Dalam kegiatan diskusi sangat membantu peserta didik mendapatkan informasi baru mengenai pertanyaan yang muncul di fikiran mereka.

\section{5). Evaluation}

Evaluasi adalah suatu alat yang digunakan untuk mengukur dan menilai dengan cara dan aturan-aturan yang sudah ditentukan, atau bisa dikatakan bahwa evaluasi adalah proses menilai (Muryadi, 2017). Evaluasi dalam pembelajaran dilakukan oleh guru yang bersangkutan dengan tujuan untuk melihat hasil dan ketercapaian siswa dalam penguasaan meteri yang telah diberikan guru.

\section{Metode Penelitian}

Penelitian ini dilakukan di kelas XI IPA 2 MA Ma'arif Ambulu tahun ajaran 2019/2020 dengan jumlah siswa 35 siswa. Jenis penelitian yang digunakan adalah penelitian tindakan kelas (PTK) dan menggunakan pendekatan kualitatif dan kuantitatif. Penelitian ini dilakukan 
dengan dua siklus, dimana pada setiap siklusnya meliputi langkah-langkah perencanaa, pelaksanaan observasi dan pengumpulan data serta refleksi.

Variabel dalam penelitian ini terdiri dari 2 variabel yakni variabel bebas yang berupa model pembelajaran RCCDE, dan variabel terikatnya adalah aktivitas belajar siswa. Metode pengumpulan data yang dilakukan adalah wawancara dan lembar observasi aktivitas belajar siswa. Indikator keberhasilan dalam sebuah penelitian adalah tolok ukur dari berhasil atau tidaknya penelitian yang telah dilakukan. Indikator keberhasilan dari aktivitas belajar siswa dari siklus I dan siklus II jika hasil yang didapat $\geq 63 \%$ sesuai dengan skor aktivitas belajar modifikasi dari (Nurpratiwi, 2015).

\section{Pembahasan}

Berdasarkan penelitian yang bersumber dari hasil wawancara dan hasil observasi aktivitas selama pembelajaran berlangsung di kelas XI IPA 2 MA Ma'arif Ambulu, terdapat pengaruh aktivitas belajar siswa dengan diterapkannya model pembelajaran RCCDE. Hal ini dapat di lihat pada grafik berikut ini:

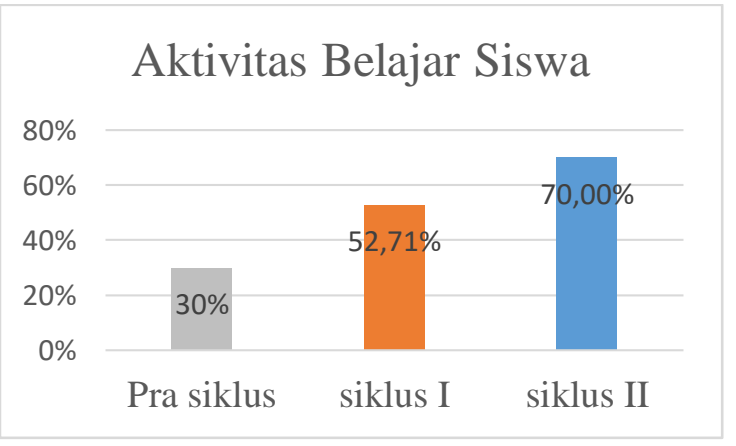

Sumber : data diolah

Gambar. Peningkatan Aktivitas Belajar Siswa Pra Siklus, Siklus I dan Siklus II.

Dari hasil grafik tesebut dapat disimpulkan bahwa penggunaan model pembelajaran RCCDE memberikan pengaruh terhadap aktivitas belajar siswa. Sebelum diterapkan model pembelajaran RCCDE, aktivitas belajar siswa hanya mencapai $30 \%$ dengan kualifikasi kurang aktif, kemudian saat penelitian siklus I berlangsung hasil yang di dapatkan hanya mencapai $52,71 \%$ saja dengan kualifikasi cukup aktif. Dari prasiklus ke siklus I terdapat peningkatan sebesar 22,71\%, namun masih belum mencapai kriteria ketuntasan yang diinginkan. Kemudian dilakukan penelitian kembali di siklus II dan mendapatkan hasil sebesar 70,00\% dengan kualifikasi aktif. Pada siklus II ini hasil yang di capai sudah mencapai kriteria yang diinginkan. Karena hasil yang di dapatkan siswa-siswi aktif dalam mengikuti pembelajaran maka dapat disimpulkan bahwa model pembelajaran RCCDE sangat efektif untuk digunakan sebagai model pembelajaran di kelas.

Efektifitas model pembelajaran juga di buktikan dari penelitian sebelumnya, yakni pada penelitian yang dilakukan oleh (Laili, 2019) bahwa model pembelajaran RCCDE berpengaruh terhadap hasil belajar siswa kelas VIII MTs. Al-Hidayah Karangharjo Silo. Dan pada penelitian yang dilakukan oleh (Soleha, 2019) juga membuktikan bahwa pada penelitiannya model pembelajaran RCCDE juga memiliki pengaruh terhadap keterampilan berfikir kritis siswa pada materi pencemaran lingkungan di kelas VII SMPN 2 Bangsalsari.

Dari hasil penelitian yangtelah dilakukan, maka dapat disimpulkan bahwa model pembelajaran RCCDE memiliki kelebihan yang pertama adalah: siswa dapat mudah memahami materi yang dipejari, karna salah satu langkah langkah dari model pembelajaran RCCDE ini adalah mengkoneksikan konsep map dengan konsep ilmu sesungguhnya. Kedua, langkah-langkah 
pada model pembelajaran RCCDE membantu siswa untuk melakukan kegiatan dasar dalam belajar atau memahami suatu konsep pembelajaran. Ketiga, model pembelajaran RCCDE ini dapat mendorong siswa untuk memiliki sikap bekerja sama, disiplin, dan belajar memahami suatu konsep masalah.

Kemudian kekurangan dari model pembelajaran RCCDE adalah : pertama, membutuhkan alokasi waktu yang cukup panjang untuk melakukan rangkaian langkah-langkah model pembelajaran RCCDE. Kedua, menuntut siswa untuk suka membaca.

\section{Kesimpulan}

Berdasarkan penelitian yang telah dilakukan dari analisis data maka dapat diambil kesimpulan bahwa model pembelajaran RCCDE dapat meningkatkan aktivitas belajar siswa kelas XI IPA 2 MA Ma'arif Ambulu, dengan hasil analisis pada siklus I sebesar 52,71\% kualifikasi cukup aktif, dan analisis pada siklus II mencapai 70,00\% dengan kualifikasi aktif.

Hasil tersebut membuktikan bahwa model pembelajaran RCCDE sangat efektif untuk digunakan sebagai model pembelajaran IPA, karna dapat meningkatkan aktivitas belajar siswa.

\section{Daftar Pustaka}

Afandi, Muhammad. DKK. 2013. Model dan Metode Pembelajaran Di Sekolah. Semarang. UNISSULA PRES. $2013 . \quad$ Hal.15. http://research.unissula. ac.id $<05$ Januari 2020>

Khikmayanti, Afro, et al. 2012. "Pengaruh Pendekatan Pakem Berbantuan Peta Konsep Acak Terhadap Hasil Belajar Siswa". Jurnal Penelitian. Semarang. Universitas Negri Semarang. http://journal.unnes.ac.id

Januari 2020>

Laili, Ade Fushilatul, et al. 2019. "Pengaruh Model Pembelajaran RCCDE (Reading Concept Map Connection Discussion Evaluation) Terhadap Hasil Belajar Siswa Pada Sistem Pernafasan di MTs AlHidayah". Jurnal Bioshell. Vol. 08 No. 01: 471- 476

Muryadi, Agustanico Dwi. 2017. Model Evaluasi dalam Penelitian Evaluasi. Jurnal Ilmiah. Vol.3 No.1 (3). http://ejournal.utp.ac.id/index.php $\angle \mathrm{JIP} /$ article/download/53/522/pdf . <04 Januari 2020>

Nurpratiwi, Rahma T. et al. 2015. Peningkatan Aktivitas dan Prestasi Belajar Siswa Melalui Metode Picture and Picture Dengan Media Audio Visual Pada Mata Pelajaran Geografi di Kelas XI IPS 2 SMA Negri 1 Bantarkawung. Jurnal Geoedukasi. Vol. IV No. 2. https://media.net.com/media/pub lication/55632-ID-peningkatanaktivitas-dan-prestasi-belajar. pdf.

Prianto, Tri Puji. 2017. Metode Diskusi Makromedia Flash Untuk Meningkatkan Hasil Belajar Alat Ukur Mekanik. Jurnal Taman Vokasi.https://jurnal.ustjogja.ac.id/ tamanvokasi/article/download/pd f. $<4$ Januari 2020>

Slameto. 2013. Belajar dan Faktor-faktor yang Mempengaruhinya. Jakarta: PT Rineka Cipta

Soleha, Arifatus, et al. 2019. Pengaruh Model Reading Concept Connection Discussion Evaluation (RCCDE) Terhadap Berfikir Kritis Pada Materi Pencemaran Air. Jurnal Bioshell. Vol. 08 No. 01: 459-463

Suarjo. 2016. Upaya Peningkatan Keaktifan dan Prestasi Belajar Siswa 
Melalui Pendekatan Teknik Berpikir, Berpasangan, Berbagi Pada Mata Pelejaran PKN di Kelas IV SDN 07 Kabawetan. Jurnal Ilmiah Pendidikan Guru Sekolah Dasar. Bengkulu

Sunarto, Ledy. 2013. Peningkatan Keaktifan Belajar Siswa Melalui Strategi Group Investigation Pada Mapel Pkn Materi Perundangundangan Siswa Kelas V Sd Negeri 01 Gumeng Kecamatan Jenawi Kabupaten Karanganyar Tahun Pelajaran 2012/2013. Jurnal Publikasi. Surakarta

Unay, Fiska B, et al. 2019. "Pengaruh Model Pembelajaran RCCDE Terhadap Hasil Belajar Siswa di Kelas VIII MTs Nurul Ali Pada Sistem Ekskresi Manusia". Jurnal Bioshell. Vol. 08 No. 01 : 464-470

Wibowo, Nugroho. 2016. Upaya Peningkatan Keaktifan Siswa Melalui Pembelajaran Berdasarkan Gaya Belajar Di SMK Negeri 1 Saptosari. Jurnal Electronic, Informatics, and Vocational Education(ELINVO). Gunung Kidul. https://journal. uny.ac.id 